\title{
On Being A Faculty \\ Member Or Things Your \\ Dissertation Adviser Never \\ Told You
}

\section{Richard W. Thompson}

Western Washington University

\section{Jim Turner and Robert Boice}

California State University, Long Beach

"For me, perhaps for most of us, it's the hardest experience we've had in our lives."

"I was very naive. I had trouble being called 'doctor.' There were so many different things to learn to do."

"I'm happy to be teaching, I enjoy research, I thoroughly like being a professor. I don't like all the pressures-sometimes it's just too much. I thought I would have a personal life, but my work is consuming all my time."

"The toughest thing is to do a good job with a career that could consume all available time, pay attention to a spouse and children, publish or perish, teach well, lead an examined life, and keep out of debt."

Thus speak new faculty during their first year as professors (Sorcinelli \& Gregory, 1987; Turner \& Boice, 1987b). In the decade ahead, up to fifty

From To Improve the Academy: Resources for Student, Faculty, and Institutional Development, Vol. 7. Edited by J. Kurfiss, L. Hilsen, S. Kahn, M.D. Sorcinelli, and R. Tiberius. POD/New Forums Press, 1988. 
percent of the current faculty will reach retirement age and an increasing number of new faculty will join the ranks of professors (Diner, 1985; George and Winfield-Laird, 1984; Jarvis, 1987). Because, for the most part, we don't prepare the professor-to-be in graduate school for the realities of the academy, many may suffer; some talented people may even be driven away (Bowen \& Schuster, 1985; Seldin, 1987). Even for those who survive the transition from graduate student to faculty status, those first few years will be difficult. Graduate students are trained to be experts in their discipline and skillful scholars, but most aren't taught about the qualities of being a "good" colleague and a "good" academic citizen (Buxton, 1956; Lowman, 1984; Morris, 1970; Professor X, 1973; Vairo \& Perel, 1969). Although many papers and books give advice to new faculty concerning teaching and research, little has been written about the rest of academic life: what to expect in the new position and how to behave as a professor (Buxton, 1956; Eble, 1983, Lowman, 1984; McKeachie, 1986; Morris, 1970; Udolf, 1976; Vairo \& Perel, 1969).

Through our roles as a department chair and as faculty developers, we have observed new faculty closely and have become aware of their plight. The following is a distillation of advice from a number of sources including relevant literature, our extensive experiences with new faculty and what new professors have to say about those first few years. It is presented to help new faculty members (or those re-entering after an absence from academia) adapt more quickly and with less pain to their new environment. This essay is also advice to chairs, deans and faculty development personnel about the problems, and some solutions to them, that new faculty face as they enter the academy.

Writers of advice to young professors are disinclined to approach the matter from multiple perspectives. And yet that is precisely what is required. The beginning assistant professor must realize that his or her perspective is limited and prone to systematic bias. A first step toward professional maturity is to recognize that one's students, colleagues, chairperson and higher administrators have their own point of view (Buxton, 1956; Clark, 1987; Cornford, 1978; Diner, 1985; Hanna, 1981; Jarvis, 1987; Lambreth, 1971; Noonan, 1980; Ryor, 1978).

Although as a new faculty member you may have considered some or all of the issues and problems presented in this essay, some of the solutions suggested may not have occurred to you. And perhaps the knowledge that you are not alone in your trials may be comforting to you.

Despite the somewhat contrary tone of what follows (advice to new faculty is often negative in tone) be assured that the life of the academician is great and most of us wouldn't choose any other (Clark, 1987; Livsey, 1975; Professor X, 1973). Although the first years may be stressful at times 
and you may feel terribly busy, you will also find it to be more exciting and satisfying than almost anything else you have experienced. To quote a beer commercial, "It doesn't get any better than this."

\section{Out of the Nest}

As a new faculty member, you may be disappointed in the quality of the students, faculty colleagues, research support and opportunities, recognition, and intellectual stimulation and challenge you find in your first teaching job. A moment's thought will reveal some of the causes of these disappointments. When you take your first teaching job, you will probably have moved from a prestigious Ph.D.-granting "research university" to one that is smaller and less prestigious. The last students you had the most contact with were other graduate students, most working on their doctorates; undergraduate students, even Masters students, can hardly compare. Your new faculty colleagues may be less famous than your dissertation director, and the bulk will be much more senior in age (Fink, 1984; George \& Winfield-Laird; 1984; Long, Allison, \& McGinnis, 1979). As a matter of fact, you may be the first new faculty member hired in over a decade (Jarvis, 1987). (You may also be saddled with the awesome task of "turning this department around in terms of scholarship.")

Even if your new school is not a research university and provides little, if any, support for research, your new colleagues and the administration still may expect (demand) that you do research in order to get tenure (Jarvis, 1987). And the support that is available may be tightly controlled by older faculty who may or may not be productive scholars. You may not get your share. It is very important for you to be flexible about your research during these first years. You can't wait for that "megabucks" piece of equipment or grant to get your research under way; you've got to go with what's available. One way of getting some research going would be to develop collaborative research with a productive senior colleague. Being willing to change what you will do in research may be essential to your survival (Boice \& Turner, 1987; Jarvis, 1987).

Your fantasy of a community of scholars sitting around discussing the problems of your discipline may also be unfulfilled. The bull sessions you had with your peers, the graduate seminars and the meetings with your dissertation adviser were focused and highly stimulating. Yo ur new colleagues are busy with their own lives and careers. Some may be threatened by you and others simply weary of discussing the same issues again. Remember, they've been through this all before, have heard their 
colleagues' arguments on all the issues a dozen times and are, perhaps, a bit jaded or even cynical (Bowen \& Schuster, 1985; Fink, 1987; Seldin, 1987; Turner \& Boice, 1987a, 1987b).

The change from being a graduate student, when there was fairly constant praise for doing research and making class presentations, to being a faculty member where such praise is rare is dramatic, perhaps even traumatic. It may seem that no one cares whether you are doing research, struggling with your classes, having difficulty in finding a place to live, or having problems with the rest of your life. Even your department chair's interest may seem driven by other than altruistic motives. You may find that the most sympathetic and concerned individual in the department is the secretary (Lambreth, 1971; Lowman, 1984).

Here you are, finally out of school and in your first professional position. You have just finished years of effort and, at least some agony. You've finally reached the top, earned your degree. Now you suddenly find yourself at the bottom again, faced with a new series of tests of your motivation, worth and spirit. As hard as graduate school was, you may find these first years as a professor even harder. You will be amazed at how much time it takes to prepare for your classes and to get your research going. It will be the busiest time in your life (Glidden, 1988; Sorcinelli \& Gregory, 1987; Turner \& Boice, 1987a, 1987b).

To this already disheartening list, add loneliness (Lambreth, 1971; Noonan, 1980; Turner \& Boice; 1987a, 1987b). Being in a strange town, one that isn't half as nice as the one you've just left, knowing no one and surrounded by people who don't seem to care (and most of whom you might not choose to associate with anyway), what are you to do? Don't despair; there are things you can do and the life of the professor is worth the effort (Grasha, 1987).

\section{Coping By Taking Charge}

Wise university administrations recognize the problems new faculty face and develop strategies to help them cope. If that is true at your new school, be sure to take advantage of all that is offered, even if it seems "mickey mouse" and a huge waste of your limited time (Quick, 1987; Turner \& Boice, 1987b). If your new university has not provided means to help you cope, then you will have to take charge yourself. Recognize that you have some control over your world (Grasha, 1987; Peterson \& Seligman; 1984; Phares, 1976). Other new faculty, including those who came last year, are in the same rocky boat as you; seek them out. Attend all the functions held for new faculty (no matter how trivial they may seem) and 
make an effort to meet one or more new people at each meeting. Meeting new people may be particularly difficult for those who are introverted, but the results will be worth it. When you meet other new faculty, explore their extra- professional interests. Make arrangements to go jogging, to a movie or to a concert. And be specific, don't leave it at, "Yeah, we'll have to go jogging together some time." Set a specific day and time. You must make the extra effort to make contact with other faculty if you are to avoid being lonely - even if you come to the university with your family. It is very important that you establish some social life with faculty colleagues, and other new faculty may be your best bet (Grashsa, 1987).

There are other steps you can take in your own department that will help reduce your loneliness and also speed your integration into the academy. These steps have the additional advantages of getting your colleagues to know you, an important factor at retention and tenure review time. They may also provide the opportunity for you to find a mentor (Fink, 1984; Hipps, 1980; Lambreth, 1971; McKeachie, 1979; Nelsen \& Siegel, 1980; Turner \& Boice, 1987a, 1987b).

Take the time to find out about your new department colleagues both their professional interests and their hobbies (Seldin, 1987). (You never know when you might discover another who is fascinated by warthogs.) In an ideal world, senior faculty will take the initiative, but in reality most will not. There are a number of very positive things that might result from your efforts. First, you may discover a rich source of knowledge that will aid you in teaching, research or finding your way through the maze of the university - and you must learn the maze. Second, one of the old guard may turn out to be a valued mentor who can help you establish your career. Pay particular attention to those members of the department who have been successful. Even if none of your new colleagues ends up as your mentor, some may provide valuable advice for your success. Third, mentor or not, age differences as they might be, you may find a friend or intellectual companion. Fourth, your interest in your senior colleagues may leave them with a positive attitude toward you, and that may help during retention and tenure review. Exchange guest lectures or team-teach with some of your more senior peers. This will give them an opportunity to observe your teaching and for you, perhaps, to get some pointers on your own teaching. Ask them to sit in on your classes; ask - be careful here that you don't threaten them - if you may sit in on theirs (Bakker \& Lacy, 1980; Turner \& Boice, 1987a, 1987b).

Getting to know your colleagues is important, but a word of caution is also necessary. Beneath a facade of collegiality, some departments are riddled with divisiveness. Some of your senior colleagues may try to recruit you to their side. Be slow to take sides on issues until you know what all 
the sides are and what the "real agenda" is. We're certainly not suggesting that you follow any but the dictates of your conscience, but we are suggesting that being prudent in your first year may save you difficulties later on. Avoid becoming a member of a clique. And be a little wary of those who might seek you out in the guise of becoming your mentor; they may have other motives. Gossiping about other faculty or the administration is unprofessional and your participation may get back to the subject of the gossip (Hanna, 1981).

Also recognize that in almost every department there are one or more senior faculty who have become disillusioned, bitter and cynical-carefully evaluate the advice you get from them. In general, senior faculty tend to give new faculty warnings about the administration, the chair, other faculty, what is important and what to avoid (Boice, 1987; Fink, 1984; Hanna, 1981; Lambreth, 1971; Livsey, 1975; Lowman, 1984; Noonan, 1980; Professor X, 1973; Seldin,1987). Don't let this general negativism get you down. (And don't let this essay make you paranoid!) Those who complain the loudest are still at the academy and wouldn't leave even if given the chance. Don't believe those who say, "The University would be a great place to be if it weren't for the students." Complaining about students seems to be as much a part of academia as the chalk (Hanna, 1981). Some faculty can't admit that they love their students and their role as a professor (Atkins \& Hagaseth, 1987; Clark, 1987).

\section{In Service to the Academy and Yourself}

Along with teaching and scholarship, a third area that is typically evaluated in decisions concerning retention and tenure is service to the department and university. Although service to the university is usually viewed as an essential part of the professor's work, it is often given little weight in the decision process. Contrary to what others might advise, we encourage you to become involved, in a limited way, in department or college committees (Cornford, 1978; Higham, 1974; Jarvis, 1987; Vairo \& Perel, 1969). You may be fortunate and have a department chair who assigns you to committees to get you involved, but who also protects you from too much committee work or getting only those assignments no one else wants to do. If it is apparent that as the "new kid on the block" you are being stuck with those rotten jobs, be sure to talk to your chair and seek relief.

Although service doesn't count as much as teaching or research in retention/tenure decisions, it is an essential aspect of your professional life. More importantly, faculty should participate in the formation of 
academic policy at all levels of the university (Atkins \& Hageseth, 1987; Bowen \& Schuster, 1985; Buxton, 1956; Clark, 1987; Diner, 1985; Jarvis, 1987; Ryor, 1978; Vairo \& Perel, 1969). There are several reasons why some limited participation for new faculty is especially important. First, serving on department and college committees is a part of the responsibility of all faculty members and it is important that you do your share. Second, work on committees will help you to get to know other faculty and them to get to know you. This limited contact with you may be all that many of your colleagues will ever have, so be sure to do a good job as a committee member (come on time, do your homework, listen carefully to the debate, and so forth). Treat even those who are "wrong" (i.e., disagree with your view) with courtesy. Don't be too quick to judge your new colleagues in a negative way. Where you are now, they once were; where they are now, you will be someday. Diplomacy is always a good policy. Third, the workings of the committees may give you insight into the workings of the department or college and how to get around in your new political environment. Fourth, taking an active part on committees may give you a sense of control and the feeling that you can have an impact on your world (Grasha, 1987; Quick, 1987; Seldin, 1987). A word of caution about the inpact of committee reports on the workings of a university: academia is notoriously conservative and change and new ideas, even good ones, are slow to be accepted and implemented. But if you keep on plugging away and are willing to put out the effort, eventually you'll see your ideas adopted. Remember, even the Grand Canyon started out as just a low place on the surface of the earth (Cornford, 1978).

\section{Students - The Pleasure of Their Company}

One of your greatest pleasures (and frustrations) will be your work with students (Grasha, 1987; Seldin, 1987). Most of us get excited and derive real satisfaction from talking to our students about our discipline and watching them acquire knowledge and skill in dealing with its concepts, theories and methods. Teaching is fun, and watching students grow and mature is indeed a pleasure (Jarvis, 1987). You will form relationships with some students that will last the rest of your life. But again a word of caution. It is tempting during your first years as a faculty member, especially if you have been disappointed with the level of intellectual stimulation or collegiality from your peers, to turn to your students for companionship. They are often closer to you in age, may be more stimulating intellectually than your colleagues and, in addition, may provide you with just the rewards you need but fail to get from your peers. Unlike your 
colleagues, your students recognize your brilliance as a researcher, admire your talents as a teacher and listen respectfully to your every word (Turner \& Boice, 1987b).

Of course it's okay to make friends with your students, but there are a number of reasons for avoiding having your students as your only social and intellectual companions. First, your students will only be around for a short time. One of the sad aspects of our profession is that even those students we become closest to, those we have mentored, eventually leave and go on to jobs or other schools. When students leave it is sad for them and for us too. If your only social and intellectual life is tied to students, it will be violently disrupted from time to time and it may leave you depressed (Lowman, 1984). Second, if you are to be a part of the academy, you must develop compatible relationships with at least some of your colleagues. To fail to do so will result in your being isolated from much that is important in being a professor (Noonan, 1980). Third, faculty who are intellectual and social isolates may be judged less positively than their more "assimilated" cohorts. Unfair as this may seem, it is a part of the realities of academic life (Lambreth, 1971). Finally, your peers can provide a better forum in which to test your ideas and to get judgments of the quality of your work than students can; they also will be the final arbiters of you as a professional. Analysis of the careers of professors has indicated that our relationships with our students, even the pleasures of teaching, will not sustain us throughout our careers. We need our colleagues' respect, approval and friendship to remain happy in our profession over the long haul (McKeachie, 1979; Turner \& Boice, 1987a, 1987b).

Working with students is exciting and fun - enjoy it. One way of getting this contact, especially with students in your own department who are not in your classes, is to volunteer to be an adviser. This is another example of taking charge of your life. By doing so you will not only meet students and do your department a service, but also learn, because you must, the details of department curricular policy as it affects students (Buxton, 1956; Diner, 1985).

\section{The Power of the Professor}

Faculty enjoy a very special relationship with their students. Whether we wish it or not, in addition to being intellectual guides to our students, we are also in a position of power over them. Many professional organizations and university faculty handbooks are explicit in the rules governing our relationships with students (McKeachie, 1986; Strohm, 1987). They 
tell us we must always behave toward our students in a professional way. We must treat them with respect regardless of the provocations we might perceive. To do otherwise is wrong both professionally and morally. We must never use our position to our advantage no matter how willing our advisees or students may seem - they don't really have freedom of choice. Their willing compliance may be out of fear even if they don't recognize it themselves. So we must not "use" our students to do our research, grade our papers, wash our cars and so forth unless they are paid a respectable wage for doing it (McKeachie, 1986; Strohm, 1987).

One additional "Thou shalt not" is to avoid gossiping about your colleagues with your students. Although it may be tempting, especially about some of your colleagues, it is unprofessional and what you say may get back to those who are the subject of the gossip. You must never use students to wage intramural battles within the department or university. Remember also that students believe that what they tell us will remain confidential and we must honor that confidentiality. But if a student should praise a colleague to you, pass it on; we're all hungry for those rare rewards for our teaching and your colleague will greatly appreciate the information. Of course student complaints about harassment or coercion by faculty members should be directed to the proper authority. Faculty handbooks usually describe the procedures to be followed (Strohm, 1987).

Working with students is often the most exciting and challenging part of our professional activities. Serving as a mentor for another, although difficult to do, is truly rewarding. As you can see, teaching is far more complex than simply being prepared before you go to class and presenting interesting and well organized lectures (Eble, 1983).

\section{Sex and the College Professor}

Even with today's more liberal sexual standards, we must not become involved sexually with our students or advisees - even if they are the ones who initiate the activity. Everyone agrees that sexual contact between student and professor is wrong and yet it seems to keep happening (Dziech \& Weiner, 1984). Why does a person who has always behaved ethically before suddenly violate this principle? Our guess is that we usually see our involvements with other people as unique. We believe those general principles that apply to others don't fit us in this particular situation. But they do! If you ever find yourself saying something like, "This is different than those other situations," then you know you are on the verge of making a tragic mistake. Stop! Run, don't walk, to a trusted friend and ask for his 
or her advice (A. Lewis, personal communication). This is a very difficult area and one in which it is easy to go wrong (McKeachie, 1986).

\section{The Staff of Life}

Secretaries are often the people most essential to making a department work. They usually know more about department operations than anyone else and can be of great help to the new professor. Give them your respect and courtesy. They are typically overworked and underpaid considering the centrality of their position, and a kind word of appreciation for what they do for you is important. Never ask them to do personal work or place them in an awkward position by asking them to break department rules. Make sure you always get the work you ask them to do in with plenty of lead time; departments usually have priorities for the work the staff must do. Having the staff on your side will make your job much easier; having them against you may make your job impossible (Higham, 1974).

\section{Relationship to the Department Chair}

Your department chair can be of immense help to you during those first hectic years. He or she knows the answers to many of the questions you have for surviving. Perhaps more critically, chairs are usually required to make some judgment about your continued appointment.

In addition, the chair usually makes decisions concerning the allocation of travel funds, money for supplies and equipment, the assignment of courses and graduate assistants, and so forth. The chair can help you only if he or she knows what you need. The worst that can happen is that the chair will say no to your request. When you have reached an agreement with your chair about support for any purpose, be sure to get it in writing. We advise this not because we believe chairs are dishonest or capricious (some of our best friends have been chairs) but because people often forget. One easy way to "get it in writing" is to write the chair a memo summarizing the agreement as you understood it: "My understanding is that you will support my presentation at the Phrenological Society of America by paying for my air fare to Los Angeles..." Although this doesn't guarantee you won't have problems, it may help you win your argument if your chair does forget. Of course you should keep a copy of the memo for your own records.

The chair has an investment in your success; he or she has been instrumental in hiring you and doesn't wish to have to admit to an error. In 
addition, many chairs are chairing just because they are interested in helping their colleagues be successful in their careers.

The chair can serve as a mentor in many ways. Don't be reluctant to seek his or her advice and share your concerns or problems. If you are struggling with your teaching or research, talk to the chair; he or she is going to find out about it eventually anyway and the sooner you get help, the sooner the problem can be solved. In those rare (we hope) instances in which the chair isn't really interested in helping, it will soon become obvious to you and you can seek help elsewhere (Atkins \& Hagaseth, 1987; Buxton, 1956; Higham, 1974; Turner \& Boice, 1987b).

\section{Potpourri}

Here are a number of other bits of advice that might be useful to new faculty members.

Learn the governance system and where the decisions in your department and college are really made. Be sure to follow the "chain of command"; no one likes being bypassed. Those who follow the chain of command earn the reputation for being cooperative and a "team player." Those who don't are seen as trouble makers (Boice, 1987; Livsey, 1975; Nitzsche, 1978).

One of the duties in teaching is assigning grades. One aspect of this is whether your grading fits the "norms" of the department. Of course you should assign grades to students based on your determination of what they have carned, but recognize that if you assign much higher or lower grades than your peers, it will have an impact on how they perceive you. When in doubt, discuss it with your mentor or chair (Buxton, 1956; McKeachie, 1986).

It is important that you keep careful records of the things you do that could be part of your credentials for retention/tenure review. The ad hoc committee you are spending so much time on now may be forgotten, even by you, unless you keep a record. In this "Brag File" keep a list of the students you direct in theses or independent projects, copies of syllabi for your courses, unsolicited letters of appreciation for your teaching or offcampus professional service, and anything else that will help describe the work you do. In the end you may not include any of this information in your dossier, but if you don't have it, you can't use it.

And finally a note about "dressing for success." It shouldn't make a difference, but how you choose to dress will influence how you're viewed by both your students and your colleagues. If your clothes aren't all that important to you, then adopt the norm (Eble, 1983; Nitzsche, 1978). 


\section{Is There Life After Office Hours?}

Professing is a job that has no end: there is always another journal article to read, more material to review before going to class, more data to be gathered, more writing to be done and an endless number of issues on campus that need to be dealt with now. When can you call it a day without the pangs of guilt that you haven't done it all or done it right yet? Will there ever be time for the non-academic you? For your family? Perhaps the only way to deal with this problem is to recognize that since professing will eat up all your free time, just don't have any free time (Glidden, 1988; Morris, 1970; Sorcinelli \& Gregory, 1987; Turner \& Boice, 1987a, 1987b). Let us explain.

To protect yourself from the tyranny of our profession you may have to schedule your time for yourself and with your family in the same rigid way that your classes, writing and research time are scheduled. Managing your time during these early years in which you are incredibly busy is essential to your survival (Grasha, 1987; Turner \& Boice, 1987a, 1987b).

Senior faculty and department chairs (except for some of the women among us) may not understand the conflict younger faculty with families must face. Many of us who are senior faculty were infused with a work ethic that told us that doing the job well served not only ourselves but our families. Devoting $100 \%$ of our time to the profession and academy was not only accepted, it was expected. We also were likely to have a wife (most of us were men) who could do all those other things we didn't do, such as being mother and father to our children, taking care of the lawn, and attending Little League. (Sorcinelli \& Gregory, 1987).

Younger faculty may have a different kind of consciousness; they are more often one of a professional pair, both of whom have tremendous demands on their time. In addition, younger faculty may perceive (correctly, in our view) the family to be equal to or greater than the profession in importance. As some senior women professors have known for decades, dividing time between profession and family makes meeting the demands of either role very difficult. The conflict between profession and family continues to be an especially difficult area for women faculty (Sorcinelli \& Gregory, 1987).

Dual-career couples report they frequently encounter stress as they attempt to balance career and family. The following suggestions to professional couples might help them deal with those stresses. First, good communication is critical. Couples must consult with each other about professional responsibilities and opportunities. Each must have the opportunity to achieve and to grow. Second, to avoid conflicts, the professional couple must cooperatively plan and organize their lives to take into 
account the times when work loads are heaviest (mid-terms, conference papers dealines, etc.). Third, although family and household chores should be divided on the basis of skill and preference, fairness of the division is probably more important. Hiring outside help may be a way to deal with too much to do and too little time to do it in. Hiring someone to mow the lawn may save your sanity. Fourth, couples can help to control their stress by seeking support from others in similar circumstances. Sharing ideas for solving problems can be very helpful. Fifth, couples living away from their extended families can sometimes find surrogates in their neighbors or service organizations. Finally, having a sense of your priorities and remaining flexible will be essential when you must modify your plans because unexpected work or opportunities arise (e.g., a manuscript dealine or chance to go to a conference to give a paper). As dual-career couples know, the problem is large and complex. Long-term solutions to the difficulties professional couples encounter must include the institutions as well as the individuals involved (Quick, 1987; Sorcinelli \& Gregory, 1987).

\section{A Postscript}

As we warned you, advice from more senior faculty tends to be largely negative and so has this essay been filled with warnings, cautions and "Thou Shalts" or "Thou Shalt Nots." Even though our tone may seem negative tone, we hope the very intense and real feelings of pride and joy at being a professor that most of us who are members of the academy share come through (Clark, 1987). So work hard, enjoy your classes and hold on to those passionate feelings you have about your teaching and scholarship. Before long, you will have jumped the hurdles and become tenured. Soon after that, you'll find yourself warning all the new "young turks" about the foibles and pitfalls of academe. Nowyou are one of the "old guard." Hopefully, you will not be negative or aloof with your new colleagues but will befriend them, perhaps becoming a mentor. And when you talk to them, be sure to tell them about the joys as well as the sorrows of professing.

\section{References}

Atkins, S. S., \& Hageseth, J. A. (1987, October). Faculty quality of life. Paper presented at the Twelfth Annual Conference of the Professional and Organizational Development Network in Higher Education, Kerville, TX. 
Bakker, G. R., \& Lacy, P. A. (1980). The teaching consultant. In W. C. Nelsen and M. E. Siegel (Eds.), Effective Approaches to Faculty Development (pp. 32-37). Washington, DC: Association of American Colleges.

Boice, R. (1987). Coping with difficult colleagues. The Department Advisor, 2(4), 5-8.

Boice, R., \& Turner, J. L. (1987, October). From observation to innovation with new faculty: The fieldwork component. Paper presented at the Twelfth Annual Conference of the Professional and Organizational Development Network in Higher Education, Kerville, TX.

Bowen, H. R., \& Schuster, J. H. (1985). Outlook for the academic profession. Acadame, 71(5), 9-15.

Buxton, C. E. (1956). College Teaching. New York: Harcourt, Brace Company.

Clark, B. (1987). The Academic Life: Small Worlds, Different Worlds. Princeton, N. J.: The Carnegie Foundation for the Advancement of Teaching.

Cornford, F. M. (1978). Microcosmographia Academica, Being a Guide for the Young Academic Politician. London: Bowes and Bowes.

Diner, S. J. (1985). Faculty and its discontents. Educational Record, 66(1), 60-62.

Dziech, B. W., \& Weiner, L. (1984). The Lecherous Professor. Boston: Beacon Press.

Eble, K. E. (1983). The Aims of College Teaching. San Francisco: JosseyBass.

Fink, L. D. (1984). First year on the faculty: Being there. Journal of Geography in Higher Education, 8, 11-25.

George, L. K., \& Winfield-Laird, I. (1984). Implications of an aging faculty for the quality of higher education and academic careers. In C. M. N. Mehrotra (Ed.), Teaching and Aging (pp. 5-27). San Francisco: Jossey-Bass.

Glidden, D. (1988, April, 6). A truly dedicated teacher has little time left over for writing, research or himself. Chronicle of Higher Education, pp. B1-B2.

Grasha, A. F. (1987). Short-term coping techniques for managing stress. In P. Seldin (Ed.), Coping With Faculty Stress (pp. 53-63). San Francisco: Jossey-Bass. 
Hanna, C. F. (1981). Complaint as a form of association. Qualitative Sociology, 4, 298-311.

Higham, R. (1974). The Complete Academic. New York: St. Martin's Press.

Hipps, G. M. (1980). Talking about teaching: The contributions of senior faculty to junior faculty. In W. C. Nelsen \& M. E. Siegel (Eds.) Effective Approaches to Faculty Development (pp.43-48). Washington, DC: Association of American Colleges.

Jarvis, D. K. (1987). Junior faculty development and language department quality. Invited paper presented Eastern Seminar of the Association of Departments of Foreign Languages, University of Virginia, Charlottsville, June 6, 1987.

Lambreth, A. (1971). The academic class machine. Change, 3, 40-46.

Livesey, H. (1975). The Professors. New York: Charterhouse.

Lowman, J. (1984). Mastering the Techniques of Teaching. San Francisco: Jossey-Bass.

Long, J. S., Allison, P. D., \& McGinnis, R. (1979). Entrance into the academic career. American Sociological Review, 44, 816-830.

McKeachie, W. J. (1979). Pespectives from Psychology: Financial Incentives are ineffctive for Faculty. In D. R. Lewis \& W. E. Becker (Eds.) Academic Rewards in Higher Education (pp.3-20). Cambridge, MA: Ballinger Publishing Companry.

McKeachie, W. J. (1986). Teaching Tips (8th Ed.). Lexington, MA: D. C. Heath and Company.

Morris, W. H. (Ed.) (1970). Effective College Teaching. Washington, DC: American Council on Education.

Nelsen, W. C., \& Siegel, M. E., (Eds.) (1980). Effective Approaches to Faculty Development. Washington, DC: Association of American Colleges.

Nitzsche, J. C. (1978). The junior professor's dilemma - How to save your own career. Change, 10, 40-43.

Noonan, J. F. (1980). An institute on teaching and learning for new faculty. In W. C. Nelsen \& M. E. Siegel (Eds.) Effective Approaches to Faculty Development. Washington, DC: Association of American Colleges. 
Peterson, C., \& Seligman, M. E. (1984). Causal explanations as a risk factor for depression: Theory and evidence. Psychological Review, 91, 347-374.

Phares, E. J. (1976). Locus of Control in Personality. Morristown, N.J.: General Learning Press.

Professor X (1973). This Beats Working for A Living. New Rochelle, N.Y.: Arlington House.

Quick, J. C. (1987). Institutional preventive stress management. In P. Seldin (Ed.), Coping with Faculty Stress (pp. 75-84). San Francisco: Jossey-Bass.

Ryor, J. (1978). Who killed collegiality? Change, 10(6), 11-12.

Seldin, P. (1987). Research findings on causes of academic stress. In P. Seldin (Ed.), Coping With Faculty Stress (pp. 13-21). San Francisco: Joseey-Bass.

Sorcinelli, M. D., \& Gregory, M. W. (1987). Faculty stress: The tension between the career and "Having it all." In P. Seldin (Ed.), Coping With Faculty Stress (pp. 43-52). San Francisco: Jossey-Bass.

Strohm, P. (Ed.). (1987). Statement on professional ethics. Academe, 73(4), 49.

Turner, J. L., \& Boice, R. (1987a, April). A longitudinal study of faculty careers. Paper presented at Western Psychological Association, Long Beach, CA.

Turner, J. L., \& Boice, R. (1987b, October). From observation to innovation: Surveys and field work as a basis for interventions with new faculty. Paper presented at the Twelfth Annual Conference of the Professional and Organizational Development Network in Higher Education, Kerville, TX.

Udolf, R. (1976). The College Instructor's Guide to Teaching and Academia. Chicago: Nelson-Hall.

Vairo, P. D., \& Perel, W. M. (1969). The neophyte in college teaching. Improving College and University Teaching, 17, 277-278.

\section{Notes}

1. A copy of an annotated bibliography of the references for this paper is available upon request from Richard W. Thompson, Department of Psychology, Western Washington University, Bellingham, Washington 98225. 